\title{
Analisis Kebutuhan Guru Terhadap Pengembangan Modul dalam Meningkatkan Kemampuan Berpikir Kritis Peserta Didik
}

\author{
Rifqi Pratama ${ }^{1 *}$,Mashudi Alamsyah ${ }^{1}$, Shafa Noer ${ }^{1}$ \\ ${ }^{1}$ Fakultas MIPA, Prodi Pendidikan Biologi, Universitas Indraprasta PGRI \\ *email: rifqi29pratama@gmail.com
}

\begin{tabular}{l} 
Article History \\
\hline Received: \\
12/05/2021 \\
Revised: \\
07/07/2021 \\
Accepted: \\
23/10/2021 \\
\\
Kata kunci: \\
Kebutuhan guru \\
Kemampuan \\
berpikir kritis \\
Modul
\end{tabular}

Key word: Teacher needs Critical thinking ability Module

\begin{abstract}
ABSTRAK
Tujuan penelitian ini untuk mengetahui dan menganalisis kebutuhan guru dalam mengembangkan modul yang mampu untuk meningkatkan kemampuan berpikir kritis peserta didik dalam memahami materi. Hasil analisis angket yang telah disebar di tiga sekolah negeri yang terdapat di daerah Masbagik dan Selong ditemukan bahwa guru belum pernah membuat modul dalam proses pembelajaran (80\%). Guru sebagian besar tidak mengetahui tentang kemampuan berpikir kritis $(80 \%)$. Guru hanya melihat hasil belajar sebagai penilaian (100\%). Guru ingin mengembangkan modul yang mampu meningkatkan kemampuan berpikir kritis peserta didik (100\%). Hasil analisis menyatakan perlunya untuk mengembangkan modul yang mampu membantu peserta didik dalam proses belajarnya dan modul tersebut juga mampu untuk meningkatkan kemampuan berpikir kritis dari peserta didik selama proses belajar.
\end{abstract}

\section{ABSTRACT}

The purpose of this study was to identify and analyze the needs of teachers in developing modules that are able to improve students critical thinking ability in understanding the lesson. From the results of the questionnaire analysis distributed in three public schools in Masbagik and Selong, it was found that teachers had never made modules in the learning process (80\%). Teachers mostly do not know about critical thinking ability (80\%). Teachers only see learning outcomes as an assessment (100\%). The teacher wants the development of modules that can improve students critical thinking ability (100\%). The results of the analysis state the need to develop modules that are able to help students in the learning process and these modules are also able to improve the critical thinking abilities of students during the learning process.
\end{abstract}

Copyright (C) 2022 LPPM Universitas Indraprasta PGRI. All Right Reserved

\section{PENDAHULUAN}

Perubahan kurikulum pada satuan pendidikan dari kurikulum KTPS menjadi kurikulum 2013 membuat perubahan strategi, metode maupun model dalam kegiatan pembelajaran di sekolah, khususnya lagi pembelajaran yang ada di dalam kelas juga menjadi berubah. Pada kurikulum 2013 guru dituntut untuk lebih memantapkan kemampuan berpikir yang dimiliki oleh peserta didik dalam pembelajaran. Kurikulum 2013 menjadikan guru sebagai fasilitator dalam kegiatan pembelajaran untuk membantu peserta didik dalam menemukan informasi baru terkait materi yang di pelajarinya, atau dengan kata lain guru bukan menjadi pusat informasi (teacher center) dalam menemukan konsep secara sepenuhnya dalam proses belajar mengajar di dalam kelas. Hal tersebut menjadikan peserta didik lebih mandiri dan aktif untuk mencari dan menemukan konsep atau materi dari pembelajarannya melalui berbagai literatur yang tersedia baik secara konvensioal maupun online.

Salah satu tujuan dari kurikulum 2013 adalah mengasah dan mengelaborasi kemampuan berpikir dari peserta didik, kemampuan peserta didik dalam mengolah cara berpikirnya ini disebut juga dengan kemampuan berpikir kritis. Hal ini sejalan dengan pembelajaran abad ini yang menuntut peserta didik lebih kreatif, dan mampu berkomunikasi dengan baik, mampu berkolaborasi, dapat memecahkan masalah yang dihadapi, dan mampu berpikir secara 
kritis (Hosnan, 2014). Berpikir menurut Bloom adalah kemampuan intelektual yang mampu digunakan untuk menganalisis, mensintesis, dan mengevaluasi, dengan kata lain kemampuankemampuan di atas dapat dikatakan sebagai kemampuan berpikir kritis.

Critical diambil dari bahasa bangsa Yunani yaitu kritikos yang bermakna "kearifan atau kemampuan untuk menilai atau mengambil keputusan". Berpikir kritis adalah kumpulan kemampuan dan keterampilan yang kita gunakan setiap hari yang diperlukan untuk pengembangan intelektual dan pribadi kita sepenuhnya (Boss, 2010). Menurut (Freeley, 2000) berpikir kritis merupakan kemampuan untuk menganalisis, mengkritik, dan menganjurkan gagasan. Untuk alasan induktif dan deduktif, dan untuk mencapai kesimpulan faktual atau menghakimi berdasarkan kehati-hatian yang diambil dari pernyataan keyakinan pengetahuan yang tidak ambigu. Berpikir kritis adalah kemampuan untuk menganalisis dan mengevaluasi informasi dengan cara mengumpulkan pertanyaan dan masalah yang penting, merumuskan dengan jelas, mengumpulkan, dan menilai informasi yang relevan, menggunakan ide-ide abstrak, berpikir secara terbuka, dan berkomunikasi secara efektif dengan orang lain (Duron, 2006). Facione (2011) menyatakan pendapatnya tentang kemampuan berpikir kritis, menurut Facione berpikir kritis merupakan kemampuan diri dalam memutuskan sesuatu yang mampu melibatkan proses interpretasi, kemudian proses analisis, kemudian melakukan evaluasi, infrensi hingga mampu memaparkan suatu bukti berdasarkan temuan yang didapat dari referensi atau konsep yang dimiliki atau metodologi yang tersedia yang sesuai dengan kriteria atau pertimbangan kontekstual yang menjadi dasar dibuatnya suatu keputusan. Berpikir kritis juga bisa sebagai proses kompleks yang melibatkan ranah kognitif yang tingkat tinggi di dalam proses menerima informasi. Ennis (2011) menambahkan terkait dengan kemampuan berpikir kritis, menurutnya kemampuan berpikir kritis merupakan suatu kemampuan berpikir yang reflektif dan memiliki alasan yang difokuskan pada apa yang dipercayai atau yang telah dilakukan. Ennis (2011) menyatakan bahwa kemampuan berpikir kritis meliputi kemampuan dalam klarifikasi dasar. Kemampuan ini sebagai dasar dari pengambilan keputusan, menyimpulkan temuan, memberikan penjelasan dari temuan lebih lanjut, perkiraan dan integrasi dari sebuah temuan yang didapat, dan kemampuan tambahan.
Pembelajaran sains merupakan proses kontruksi pengetahuan (sains) melalui aktivitas berpikir anak. Dalam keadaan ini, anak diberikan kesempatan untuk mengembangkan pengetahuannya secara mandiri melalui proses komunikasi yang menghubungkan pengetahuan awal yang dimiliki dengan pengetahuan yang akan mereka pelajari dengan metode penemuan dari sumber yang ada. Dengan demikian, kondisi seperti ini akan membuat anak berdaya dalam memecahkan masalahnya (Rohand, 1998). Pembelajaran sains bisa mengasah kemampuan berpikir kritis dari peserta didik, tentunya dengan mengajarkan peserta untuk menggunakan kemampuan berpikir kritisnya adalah salah satu tujuan dari pendidikan itu sendiri (Kazempour, 2013) dan tentunya juga implementasi dari kurikulum 2013. Guru harus bisa membimbing peserta didik untuk memunculkan dan melatih kemampuan berpikir kritis dari peserta didik di dalam proses belajar, hal ini tentunya dapat membantu para peserta didik untuk menemukan informasi belajar secara mandiri dan tentunya juga membuat peserta didik lebih aktif membuat atau menciptakan struktur kognitif yang ada pada diri peserta didik tersebut (Patonah, 2014).

Agar tujuan tersebut tercapai, guru perlu membuat kelas yang interaktif agar pembentukan kemampuan berpikir kritis peserta didik terlihat opimal, peserta didik perlu dilihat sebagai pemikir bukan sebagai pendengar saja dan guru hanya sebagai fasilitator dan motivator yang membantu peserta didik dalam proses belajar mengajar di dalam kelas (Nuryanti, 2018). Selain itu guru bisa menerapkan metode yang dapat membantu peserta didik dalam mencapai tujuan pembelajaran sainsnya. Salah satu metode yang bisa di terapkan dalam mencapai tujuan tersebut dengan menggunakan modul belajar dalam proses pembelajaran di kelas. Modul adalah suatu bahan ajar yang isi dari modul tersebut relatif singkat dan spesifik yang disusun untuk mencapai tujuan pembelajaran. Modul pada umunya memiliki suatu rangkaian kegiatan yang terkoordinir dengan rapi yang berhubungan dengan materi, latihan bagi peserta didik, serta diberikan media didalamnya (Lasmiyati, 2014). Selain itu modul juga didesain agar peserta didik diberi kesempatan untuk bekerja dalam merumuskan prosedur dan menganalisis hasil dan mengambil kesimpulan secara mandiri. Sedangkan dalam menentukan topik, pertanyaan, dan bahan penunjang guru hanya sebagai fasilitator (Amri, 2012). Modul juga perlu dilihat kualitasnya, menurut Fitri dkk. (2013) kualitas modul dapat dilihat dari beberapa hal, seperti: aspek kelayakan 
isi dari modul tersebut, isi dari modul harus mencakup kesesuaian dengan SK dan KD dari materi peserta didik atau tingkatan dari peserta didik yang akan diberikan modul tersebut. Modul juga harus memiliki manfaat untuk menambah wawasan dari peserta didik. Aspek selanjutnya yang harus dimiliki di dalam modul adalah aspek kelayakan bahasa. Aspek kelayakan bahasa ini mencakup keterbacaan, kejelasan informasi, kesesuaian dengan kaidah bahasa Indonesia yang baik dan benar. Aspek selanjutnya yang harus dimiliki modul adalah aspek penyajian, yang mencakup keterjelasan tujuan yang dicapai yang tertuang pada indikator, urutan sajian, pemberian motivasi, memberikan daya tarik berupa gambar atau sesuatu yang bisa menarik minat belajar peserta didik, kelengkapan materi. Modul juga bisa dijadikan sebagai media pembelajaran pada proses belajar. Aspek selanjutnya adalah kelayakan grafik yang mencakup penggunaan font atau bentuk huruf pada penulisan modul (jenis, ukuran), lay out atau tata letak, ilustrasi dan tentunya desain tampilan (Susilo dkk., 2016).

Kelebihan pembelajaran dengan menggunakan modul yaitu modul dapat memberikan umpan balik sehingga pada proses pembelajaran ada interaksi yang terjadi, sehingga guru dapat langsung berinteraksi dengan peserta didik dan mengetahui kekurangan dari apa yang mereka temui dan segera memperbaikinya. Modul harus memiliki tujuan pembelajaran yang jelas sehingga kinerja peserta didik dalam proses pembelajaran terarah untuk mencapai tujuan dari pembelajaran yang dilaksanakan di kelas. Modul yang di desain dengan semenarik mungkin akan mudah dipelajari oleh peserta didik dan tentunya akan menimbulkan minat dan motivasi dari peserta didik untuk belajar. Modul juga bersifat fleksibel karena muatan materi pada modul dapat dipelajari oleh peserta didik dengan cara dan kecepatan yang berbeda antara satu peserta didik dengan peserta didik lainnya dan tentunya modul juga bisa di akses dimana saja oleh peserta didik. Modul juga mampu membantu peserta didik dalam melaksanakan kerja sama dengan rekan peserta didik lainnya. Latihan soal juga dapat membantu peserta didik untuk melihat kemampuannya didalam menyelesaikan soal latihan tersebut kemudian mendiskusikannya dengan peserta didik lainnya, hal tersebut membuat peserta didik menemukan kelemahannya dalam menyelesaikan soal dan mampu meningkatkan kemampuannya dalam menyelesaikan soal lain (Lasmiyati, 2014). Modul interaktif yang diberikan kepada peserta didik di dalam proses belajar mengajar tentunya dapat mengembangkan kemampuan dalam berpikir secara kritis, dan bisa jadi mengarah kepada kemampuan berpikir tingkat tinggi, kemampuan dalam berpikir tingkat tinggi tergolong di dalam kemampuan berpikir kompleks. Hal tersebut tentunya sudah mencakup didalamnya adanya pemecahan masalah, kemudian melakukan pembuatan keputusan, berpikir kritis, dan munculnya berpikir kreatif. Model kemampuan berpikir kritis sangat cocok diterapkan untuk sekolah tingkat menengah (Yayan, 2012).

Sasaran utama dari pembelajaran aktif adalah keterlibatan peserta didik secara maksimal dalam proses kegiatan belajar, keterarahan kegiatan secara logis dan sistematis pada tujuan pembelajaran, dan mengembangkan sikap percaya pada diri peserta didik tentang apa yang ditemukan dalam proses belajar. Selain modul guru juga bisa menggunakan model dalam proses pembelajarannya, misalnya guru bisa menggunakan model pembelajaran inkuiri terbimbing dalam proses belajar. Pada penelitian terkait pengembangan modul terintegrasi model inkuiri terbimbing, menyatakan bahwa dengan pengintegrasian model belajar dalam hal ini inkuiri terbimbing mampu meningkatkan kemampuan berpikir kritis peserta didik (Pratama \& Alamsyah, 2020). Hal ini menunjukkan bahwa model inkuiri terbimbing dapat mendukung peserta didik dalam mengembangkan kemampuan berpikir kritisnya. Sejalan dengan penelitian yang dilakukan oleh Santi (2016) yang menyatakan bahwa penggunaan model inkuiri terbimbing dalam proses pembelajaran IPA yang berbantu dengan e-modul mampu meningkatkan keterampilan berpikir kritis dari peserta didik yang diajarkan. Penelitian yang dilakukan oleh Kurniawati (2014) menyatakan bahwa kemampuan berpikir kritis peserta didik yang belajar menggunakan model inkuiri terbimbing integrasi peer teaching lebih tinggi dari pada pembelajaran yang menggunakan model konvensional.

Berdasarkan paparan di atas maka dilakukanlah observasi di SMA Negeri yang telah menggunakan kurikulum 2013 dalam proses belajar mengajarnya di sekolah. Berdasarkan observasi yang peneliti lakukan, peneliti memperoleh informasi bahwa sebagian besar guru belum pernah membuat modul belajar selama proses belajar mengajar, guru tidak menggunakan model pembelajaran di dalam kegiatan pembelajaran di kelas dan belum pernah melakukan pengukuran terhadap kemampuan berpikir kritis dari peserta didik. Informasi inilah yang menjadi landasan dasar peneliti dalam menggali kebutuhaan guru terhadap pengembangan bahan ajar berupa modul yang 
berbasis model untuk meningkatkan kemampuan berpikir kritis dari peserta didik yang diajar.

\section{METODE PENELITIAN}

Penelitian ini merupakan penelitian deskriptif. Data penelitian diperoleh melalui penyebaran angket non-tes kepada para guru di sekolah yang dituju sebagai subjek penelitian. Subjek penelitian ini adalah guru kimia SMA Negeri di Lombok Timur, yang terdiri dari 2 guru SMA Negeri yang berada di daerah Masbagik, 2 guru SMA Negeri yang berada di daerah Selong, dan 1 guru SMA Negeri di daerah Selong lainnya. Observasi dilakukan sebelum dilakukannya penyebaran angket terhadap proses pembelajaran dan kebutuhan guru, kemudian guru diberikan angket untuk mengetahui kebutuhan guru. Angket untuk mengetahui kebutuhan guru tersebut terdiri dari 35 pertanyaan terbuka, setelah itu hasil angket kemudian dianalisis berdasarkan persentase jawaban yang diberikan oleh guru dalam menjawab angket. Hasil dari angket tersebut dianalisis untuk mengetahui kebutuhan guru terhadap modul yang ingin dikembangkan yang mana modul ini mampu untuk meningkatkan kemampuan berpikir kritis.

\section{HASIL DAN PEMBAHASAN}

Penelitian ini bertujuan untuk mendeskripsikan kebutuhan guru terhadap pengembangan modul yang dapat menunjang kemampuan berpikir kritis peserta didik dalam melaksanakan pembelajaran. Hasil angket kebutuhan dijadikan sebagai dasar untuk dilakukannya pengembangan sumber belajar berupa modul. Modul yang dikembangkan berperan sebagai bahan ajar bagi para peserta didik dalam belajar. Modul merupakan salah satu bahan ajar yang dicetak yang disusun secara sistematis dan menggunakan bahasa yang mudah dipahami oleh peserta didik sesuai dengan tingkat pengetahuan dan usia peserta didik, yang dapat digunakan sebagai bahan belajar mandiri dengan bimbingan minimal dari pendidik (Prastowo, 2012)

Hasil analisis angket kebutuhan guru disajikan pada Gambar 2.

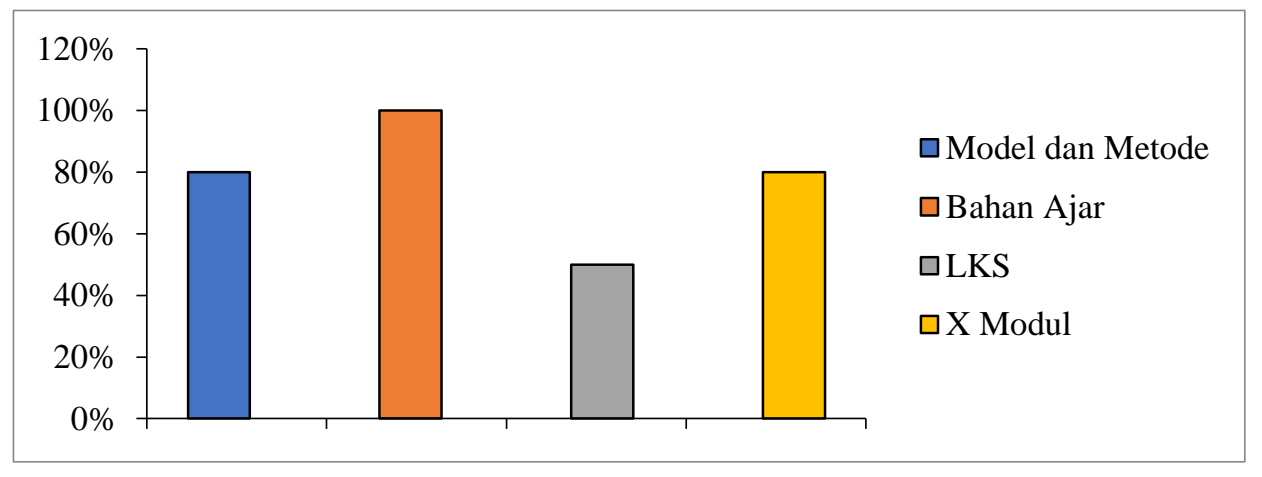

Gambar 1. Hasil angket kebutuhan guru

Gambar 1 memperlihatkan bahwa guru mengajarkan materi kimia masih menggunakan metode dan model ceramah, tanya jawab, dan diskusi $(80 \%)$, sisanya pada proses pembelajaran guru pernah menggunakan model pembelajaran CTL, penggunaan model pembelajaran CTL tidak dilakukan di semua materi belajar di kelas. Pada penggunaan bahan ajar, guru menggunakan bahan ajar berupa buku paket sebagai pedoman dalam belajar mengajar (100\%). Penggunaan bahan ajar dengan buku paket ini merupakan penggunaan bahan ajar tunggal di sekolah yang diteliti, karena memang guru tidak mengembangkan atau membuat bahan ajar lain sebagai bahan penunjang tambahan di dalam proses belajar mengajar. Hasil analisis selanjutnya menyatakan beberapa guru pernah membuat LKS sebagai tambahan bahan ajar
(50\%), akan tetapi tidak memuat tahapan dari kemampuan berpikir kritis (0\%). Pembuatan LKS pada proses belajar ini hanya pada materi tertentu dan dikarenakan adanya hal lain yang menyebabkan guru harus membuat LKS. Hasil analisis angket selanjutnya adalah guru tidak pernah membuat modul belajar dalam proses kegiatan belajar mengajar di dalam kelas $(80 \%)$. Kebanyakan guru tidak membuat modul dikarenakan ketersediaan waktu yang dimiliki oleh guru di luar kelas, maka guru lebih suka menggunakan buku paket di dalam proses belajar mengajar yang dilaksanakan di dalam kelas.

Tahapan dari kemampuan berpikir kritis yang terdapat pada buku paket yang digunakan oleh guru dalam proses kegiatan belajar mengajar dijelaskan pada Gambar 2. 


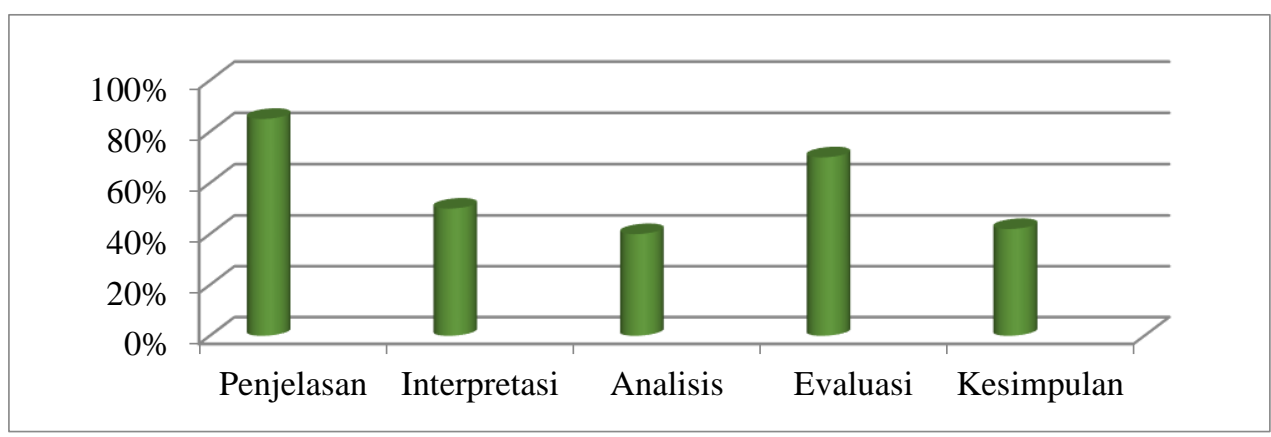

Gambar 2: Tahapan kemampuan berpikir kritis yang terdapat di buku paket

Buku paket yang digunakan oleh guru dalam proses belajar mengajar dianalisis berdasarkan indikator dari kemampuan berpikir kritis yang dikembangkan oleh Facione (2011). Buku paket yang digunakan oleh guru sebenarnya sudah memiliki tahapan yang mampu melatih kemampuan berpikir kritis peserta didik, tetapi tidak signifikan secara keseluruhan, ada beberapa tahapan yang cukup besar persentasenya dan sebagian yang lainnya sedang-sedang saja. Tahapan untuk kemampuan berpikir kritis pada bagian penjelasan memiliki persentase mencapai 85\% yang terdapat pada buku paket yang digunakan oleh guru sebagai bahan ajar dalam kegiatan belajar mengajar di kelas. Tahapan selanjutnya dari kemampuan bepikir kritis adalah tahapan interpretasi, pada beberapa buku hanya persentase dari tahapan ini mencapai 50\% yang termuat, tentunya untuk tahapan ini pada bagian buku paket masih jarang ditemukan. Kemudian tahapan selanjutnya adalah tahapan analisis yang memiliki persentase sebesar $40 \%$, tidak terlalu tinggi persentasenya tetapi termuat di dalam buku paket tersebut. Sedangkan pada tahapan evaluasi mencapai $70 \%$, tahapan evaluasi merupakan tahapan yang umum ditemukan di dalam buku paket. Tahapan evaluasi biasanya disajikan dalam bentuk soal-soal yang dapat dikerjakan oleh para peserta didik atau bahasa lainnya adalah latihan soal. Pada tahapan evaluasi pada umumnya guru melihat keberhasilan dari peserta didik dalam memahami materi, karena menunjukkan nilai dari suatu kegiatan. Tahapan yang terakhir dari kemampuan berpikir kritis yang dianalisis dari buku paket adalah tahapan kesimpulan, pada tahapan ini persentasenya adalah $42 \%$. Tahapan kesimpulan adalah tahapan di mana peserta didik membuat suatu rangkaian yang masih berhubungan indikator sebelumnya yaitu interpretasi. Jadi jika interpretasi peserta didik baik maka tentunya pada indikator atau tahapan untuk kesimpulan akan baik juga. Kesimpulan merupakan bagian yang tidak bisa dilepaskan dari proses belajar, dari kegiatan menyimpulkan ini peserta didik diharapkan mampu memahami materi yang telah didapat selama proses belajar mengajar berlangsung.

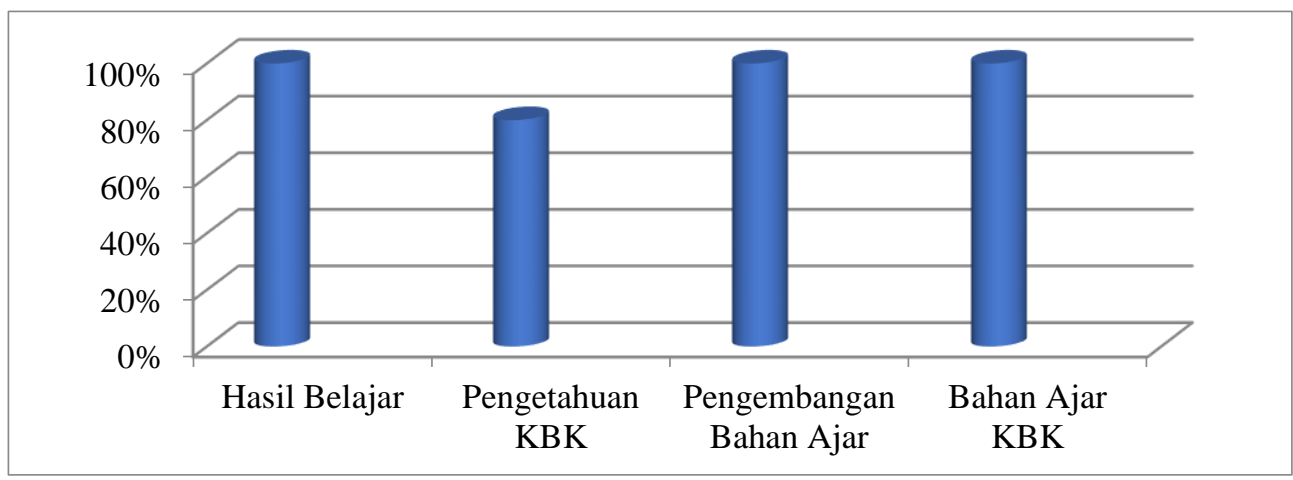

Gambar 3. Hasil analisis angket untuk hasil belajar dan pengembangan bahan ajar

Hasil analisis angket kebutuhan guru selanjutnya adalah melihat analisis yang dilakukan oleh guru selama proses belajar berupa hasil belajar, pada bagian ini ditemukan bahwa hasil belajar yang diukur oleh guru pada kegiatan belajar mengajar hanya mengukur ranah kognitif saja (100\%). Ranah kognitif adalah ranah yang paling sering diukur oleh guru karena menunjukkan suatu patokan kelulusan atau ketercapaian dalam memahami materi, tetapi pada 
kurikulum 2013 ada ranah lain atau item lain yang perlu di tinjau sebagai ketercapaian dari pembelajaran dan penguasaan materi. Hasil angket kebutuhan juga menyatakan bahwa guru kimia sebagian besar tidak mengetahui tentang kemampuan berpikir kritis (80\%). Kemampuan berpikir kritis jarang dikaji untuk melihat ketercapaian dari proses belajar mengajar jadi tidak salah jika masih banyak guru yang belum memahami atau mengetahui kemampuan berpikir kritis, maka perlu adanya kajian terkait itu. Hasil angket selanjutnya menyatakan bahwa guru juga menginginkan adanya pengembangan bahan ajar yang mampu membantu peserta didik dalam menginterpretasikan materi yang abstrak (100\%). Hal abstrak adalah hal yang akan sering ditemukan dalam proses belajar kimia, fisika dan muatan pengetahuan alam secara umum, maka perlu bahan ajar yang mampu mengakomodir itu. Guru juga memberikan masukan agar dikembangkan bahan ajar yang mampu membantu peserta didik untuk menumbuhkan kemampuan berpikir kritis (100\%). Dari hasil analisis angket tersebut dan masukan para guru yang telah mengisi angket kebutuhan guru tersebut akan dikembangkan modul yang mampu meningkatkan kemampuan berpikir kritis dalam pembelajaran kimia.

\section{KESIMPULAN}

Hasil angket kebutuhan menunjukkan bahwa guru membutuhkan adanya bahan ajar lain yang mampu menunjang proses belajar peserta didik. Bahan ajar tersebut berbentuk modul yang mampu untuk meningkatkan kemampuan berpikir kritis peserta didik dalam pembelajaran kimia. Modul yang dikembangkan diharapkan mampu untuk memberikan dampak yang positif bagi peserta didik dalam proses pembelajarannya dikelas.

Saran sebaiknya dilakukan penyebaran angket yang lebih luas, tidak hanya pada tiga sekolah saja.

\section{DAFTAR PUSTAKA}

Alwasilah, A. C. (2011). Pokoknya Kualitatif. Dasar-dasar Merancang dan Melakukan Penelitian Kualitatif. Pustaka Jaya: Jakarta.

Amri, S. (2012). Pembelajaran Kreatif dan Inovatif dalam Kelas. PT. Prestasi Pustaka: Jakarta.

Boss, J. A. (2010) Think Critical Thinking and Logic Skil for Everyday Life. McGraw-Hill: New York.

Budiarti, S., Nuswowati, M., \& Cahyono, E. (2016). Quided inquiry berbantuan e-module untuk meningkatkan keterampilan berpikir kritis. Jounal of Innovative Science Education, 5(2), 144-151.

Duron, R., Limbach, B., \& Waugh, W. (2006). Critical Thinking Framework for Any Discipline, 17(2), 160-166.

Ennis, R. H. (2011). The Nature of Critical Thinking: An Outline of Critical Thinking Disposition and Abilities. Last Revised. Emeritus Proffessor. University of Illinois.

Facione, P. A. (2011). Critical Thinking: What It Is and Why It Counts. Measured Reasons and The California Academic Press: Millbrae.

Fitri, L. A., Alimah., Kurniawan, E. S., \& Ngazizah, N. (2013). Pengembangan modul fisika pada pokok bahasan listrik dinamis berbasis domain pengetahuan sains untuk mengoptimalkan minds-on siswa SMA Negeri 3 Purworejo kelas X tahun pelajaran 2012/2013. Radiasi, 3(1), 19-23.

Freeley. A. J. (2000). Argumentation and Debate Critical Thinking for Reasoned Decision Making. Wadsworth Thomson Learning: Belmote.

Hosnan, M. (2014). Pendekatan Saintifik dan Kontekstual dalam Pembelajaran Abad 21. Ghalia Indonesia: Bogor.

Kazempour, E. (2013). The effects of inquirybased teaching on critical thinking of students. journal of social. Issues \& Humanities, 1(3), 2327.

Kurniawati, I. D. I. (2014). Pengaruh pembelajaran inkuiri terbimbing integrasi peer instruction terhadap penguasaan konsep dan kemampuan berpikir kritis siswa. Jurnal Pendidikan Fisika Indonesia, 10, 36-46.

Lasmiyati. (2014). Pengembangan modul pembelajaran untuk meningkatkan pemahaman konsep dan minat siswa. Pythagoras. Jurnal Pendidikan Matematika, 9(2), 161-174.

Nuryanti, L. (2018). Analisis kemampuan berpikir siswa SMP. Jurnal Pendidikan: Teori, Penelitian, dan Pengembangan, 3(2), 155-158.

Patonah, S. (2014). Elemen bernalar tujuan pada pembelajaran IPA melalui pendekatan metakognitif siswa SMP. Jurnal Pendidikan IPA Indonesia, 3(2), 128-133. http://dx.doi.org/10.15294/jpii.v3i2.3111.

Prastowo, A. (2012). Panduan Kreatif Membuat Bahan Ajar Inovatif. Diva Presss: Yogyakarta.

Pratama, R. (2020). Analisis Kebutuhan Guru Terhadap Pengembangan Modul Virtual Kimia Berbasis Inkuiri Terbimbing. In Seminar Nasional Sains (SINASIS 1). Jakarta: Universitas Indraprasta PGRI.

Pratama et al. Analisis Kebutuhan Guru EduBiologia Volume 2 Number 1 Januari 2022 
Sunarya, Y \& Setiadi, R. (2012). Pengembangan multimedia berbasis karakter konsep dan berorientasi pada keterampilan berpikir kristis. Jurnal Pengajaran MIPA, 17(1), 86-95.

Susilo, A., Siswandari., \& Bandi. (2016). Pengembangan modul berbasis pembelajaran saintifik untuk peningkatan kemampuan mencipta siswa dalam proses pembelajaran akutansi siswa kelas XII SMAN 1 Slogohimo 2014. Jurnal Pendidikan Ilmu Sosial, 26(1), 5055. https://doi.org/ 10.2317/jpis.v26i1.2127.

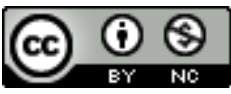

This work is licensed under a Creative Commons Attribution-NonCommercial 4.0 International License 